\title{
Finding a shadow in the dark: rediscovery of Fugler's Shadow Snake (Emmochliophis fugleri Fritts \& Smith, 1969) after 54 years, with comments on its conservation status, distribution, and the tribe Diaphorolepidini
}

\author{
Ross J. Maynard ${ }^{1 *}$, Jaime Culebras ${ }^{2}$, Sebastian Kohn ${ }^{3,4}$, Juan M. Guayasamin ${ }^{5}$, Scott J. Trageser ${ }^{1}$ \\ 1 The Biodiversity Group, Tucson, AZ, USA •RJM: ross@biodiversitygroup.org @ https://orcid.org/0000-0001-5371-3424 • ST: trageser. \\ scott@gmail.com @ https://orcid.org/0000-0001-7171-6768 \\ 2 Photo Wildlife Tours, Quito, Ecuador•jaimebio85@gmail.com @ https://orcid.org/0000-0003-2211-6605 \\ 3 Fundación Ecominga, Quito, Ecuador • sebastiankohn@hotmail.com @ https://orcid.org/0000-0002-1299-2612 \\ 4 Fundación Cóndor Andino, Quito, Ecuador \\ 5 Laboratorio de Biología Evolutiva, Colegio de Ciencias Biológicas y Ambientales COCIBA, Instituto Biósfera-USFQ, Universidad San \\ Francisco de Quito, Campus Cumbayá, Quito, Ecuador•jmguayasamin@usfq.edu.ec @ https://orcid.org/0000-0003-0098-978X \\ * Corresponding author
}

\begin{abstract}
Herein we report the second known record of Emmochliophis fugleri Fritts \& Smith, 1969, present the first color images of the species, extend its known distribution and elevational range, provide the snout-vent and tail lengths of the holotype, and demonstrate that the condition of fused prefrontals is an unreliable diagnostic character for the genus Diaphorolepis. Considering the rarity of this snake as well as the imminent threat that mining poses to the Río Manduriacu Reserve, we recommend a conservation status of Critically Endangered for E. fugleri.
\end{abstract}

\section{Keywords}

Critically Endangered, Ecuador, Imbabura, Río Manduriacu Reserve, threatened, threatened by mining

Academic editor: Cord Eversole | Received 25 October 2020 | Accepted 21 January 2021 | Published 11 February 2021

Citation: Maynard RJ, Culebras J, Kohn S, Guayasamin JM, Tregaser S (2021) Finding a shadow in the dark: rediscovery of Fugler's Shadow Snake (Emmochliophis fugleri Fritts \& Smith, 1969) after 54 years, with comments on its conservation status, distribution, and the tribe Diaphorolepidini. Check List 17 (1): 239-245. https://doi.org/10.15560/17.1.239

\section{Introduction}

The snake tribe Diaphorolepidini was recently validated and defined to include the genera Diaphorolepis Jan, 1863, Emmochliophis Fritts \& Smith, 1969, and Synophis Peracca, 1896 (Pyron et al. 2016). These snakes are relatively small and slender, distributed in the Darien of Panama and northern Andes of South America, and are reportedly diagnosed by the following apomorphies: fused prefrontals, an expanded vertebral scale row (Diaphorolepis), and expanded zygapophyses and neural spines in adults (Emmochliophis and Synophis; Pyron et al. 2016). However, even though the state of the prefrontal in Diaphorolepis is noted to be fused or divided 
by Bogert (1964) and Pérez-Santos and Moreno (1988, 1991), such variation is not recognized in more recent literature (e.g., Pyron et al. 2015, 2016). A recent molecular phylogeny supports this grouping, although the position of Emmochliophis remains unclear as tissue from this taxon has been unavailable but is suspected to be the sister-taxon of Synophis (Hillis 1990; Pryron et al. 2015, 2016).

Emmochliophis is an enigmatic genus that was described by Fritts and Smith (1969) following the discovery of a museum specimen collected from Santo Domingo de los Tsáchilas Province, Ecuador (considered within Pichincha Province at the time), which exhibited a unique condition of the trunk vertebrae that consists of expanded zygapophyses that form a rodand-groove mechanism. As a result, Fritts and Smith (1969) designated this specimen as the holotype for $E$. fugleri. Due to a lack of additional material, the taxon remained poorly described for 21 years following its original description. Hillis (1990) later determined that Synophis miops Boulenger, 1898 warranted a transfer to Emmochliophis on the basis of numerous shared characters with E. fugleri, but without knowledge of the condition of the vertebrae in E. miops. The latter character was later described by Sheil (1998). Despite the addition of E. miops to the genus, it did not yield new material as it was also known only from the holotype, collected by W.F.H. Rosenberg in northwest Ecuador in the late 19th century (Boulenger 1898). Additional specimens of either taxon would not be reported until 2018, when
E. miops was observed from Parque Nacional Natural Munchique, Cauca Department, Colombia (Vera-Pérez et al. 2018). The discovery marked the first record of the species in 120 years and yielded the first color photographs and a redescription of the species (Vera-Pérez et al. 2018, 2020). The authors also proposed standardized common names for Emmochliophis spp., suggesting Fugler's Shadow Snake for E. fugleri-a more appropriate name compared to Pinchinda Snake (a misspelling of Pichincha) listed on the Reptile Database (http://reptiledatabase.org, accessed: 2020-9-18) and therefore iNaturalist (Vera-Pérez et al. 2020).

While conducting fieldwork at the Río Manduriacu Reserve (RMR) in western Imbabura Province, Ecuador, we came across a small, dark snake and initially thought it to be one of two relatively common species of Ninia Baird \& Girard, 1853 known from the region$N$. atrata (Hallowell, 1845) is already known to occur at RMR - albeit a peculiar looking individual. However, upon closer inspection of photographs taken of the snake and a review of relevant literature, the observation was instead identified as E. fugleri. As a result, we herein report the first record of E. fugleri in 54 years, extend its known distribution nearly $100 \mathrm{~km}$ north-northeast of the type locality and expand the elevational range more than $600 \mathrm{~m}$ higher than that of the holotype, evaluate its conservation status, and present the first color photographs of the species. We also report meristic and morphometric data and reaffirm variation in the state of the prefrontals in Diaphorolepis wagneri Jan, 1863, thereby

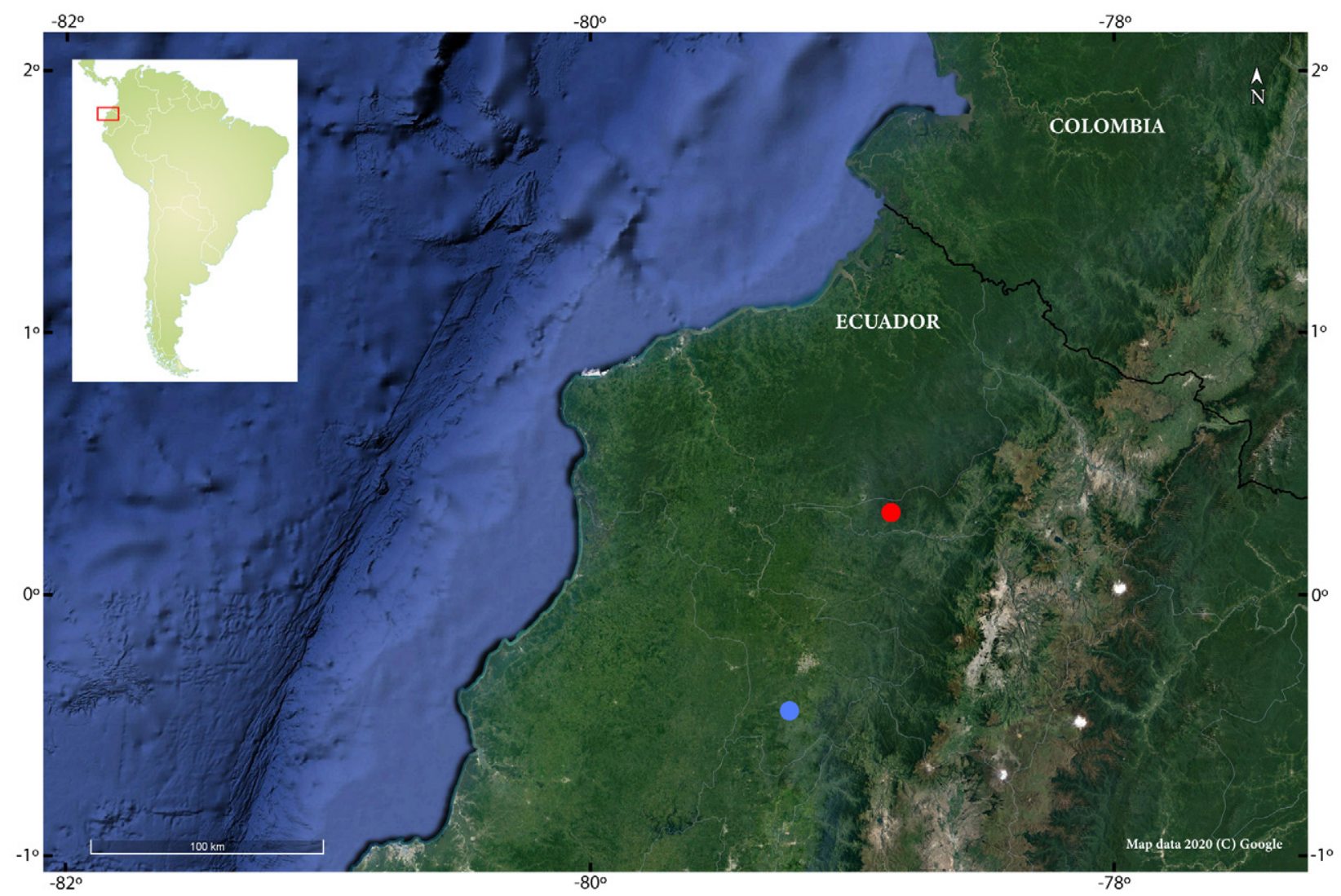

Figure 1. Distribution map depicting the two known records of Emmochliophis fugleri. Blue circle marks the type locality in Pinchincha Province, Ecuador; red circle represents the Río Manduriacu Reserve, Imbabura, Ecuador. Map data ๑ 2020 Google. 


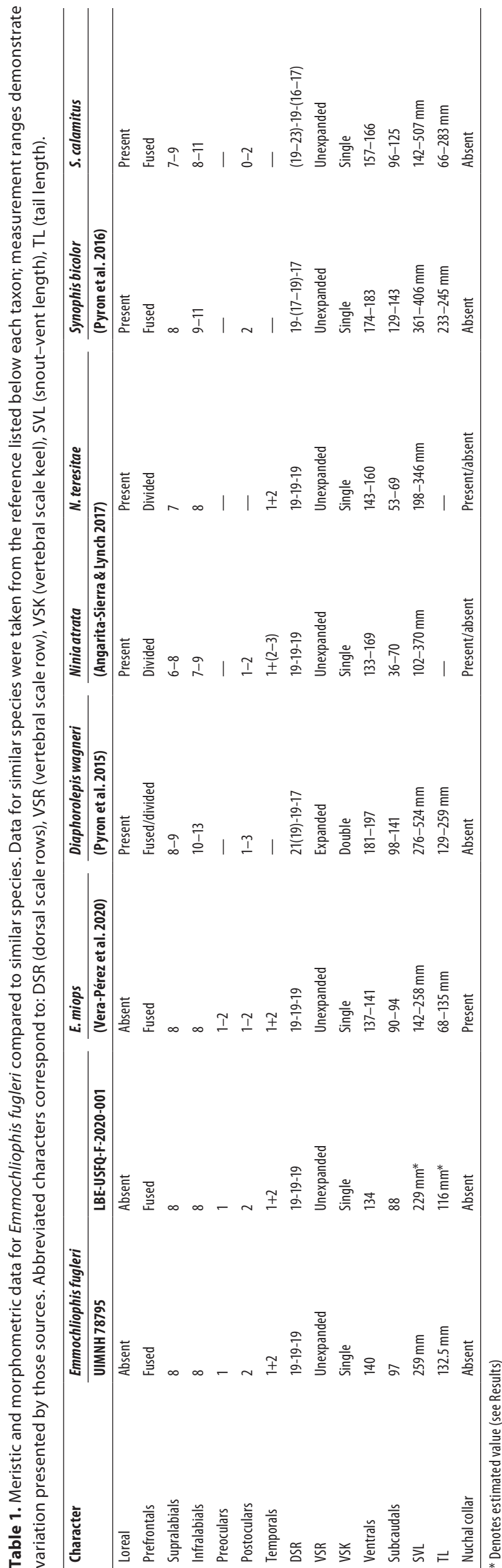

demonstrating it to be an unreliable diagnostic character for Diaphorolepis.

\section{Methods}

We conducted field surveys at the Río Manduriacu Reserve (RMR), Imbabura, Ecuador (Fig. 1). Habitat at RMR consists of mature lower montane forest and primary cloud forest, with small, moderately disturbed forest areas at the lower reaches. Data reported here was collected during an ongoing effort to study the amphibian and reptile assemblages at the reserve, with a focus on threatened taxa. Sampling methodology primarily included nocturnal visual encounter surveys along established trails in both primary and secondary forest, within small streams, and adjacent to larger streams and rivers situated within and just outside of the reserve. Time frames for when herpetofauna have been sampled for are outlined by Guayasamin et al. (2019) and Maynard et al. (2020).

The key to the species of Diaphorolepidini presented in Pyron et al. (2016) combined with the description of Emmochliophis fugleri by Fritts and Smith (1969) was used for identification. Scale counts and scutelation follow Dowling (1951). Ambient temperature and humidity were measured using a Kestrel 3500 Weather Meter. Photographs of the live specimen are indexed in the digital repository of Universidad San Francisco de Quito (USFQ). We searched for potentially overlooked observations of E. fugleri by utilizing the CalPhotos (http://calphotos.berkeley .edu), iNaturalist (http://inaturalist.org), and VertNet (http://portal.vertnet.org) databases. Images of similar species to E. fugleri were examined for distinguishing meristic and morphological characters (see Results; Table 1). Similar species were limited to those that have overlapping or nearby distributions to that of $E$. fugleri (i.e., Diaphorolepis wagerni, Ninia atrata, N. teresitae Angarita-Sierra \& Lynch, 2017, Synophis bicolor Peracca, 1896, and S. calamitus Hillis, 1990). Research was conducted under permit no. 019-2018-IC-FAU-DNB/ MAE, authorized by the Ministerio del Ambiente del Ecuador, and carried out in accordance with the guidelines for the use of live amphibians and reptiles in field and lab research (Beaupre et al. 2004) compiled by the American Society of Ichthyologists and Herpetologists, the Herpetologists' League, and the Society for the Study of Amphibians and Reptiles.

\section{Results}

\section{Emmochliophis fugleri Fritts \& Smith, 1969}

Figures 2, 3

New records. ECUADOR - Imbabura Province, Río Manduriacu Reserve; $00.3095^{\circ} \mathrm{N}, 078.8573^{\circ} \mathrm{W}, 1221 \mathrm{~m}$; 07 Mar. 2019; Scott Trageser and Ross Maynard leg.; observed in mature lower montane forest at 22:20 h, slowly moving through leaf litter adjacent to moss-covered boulders along the embankment of a narrow, 15-m wide 
A

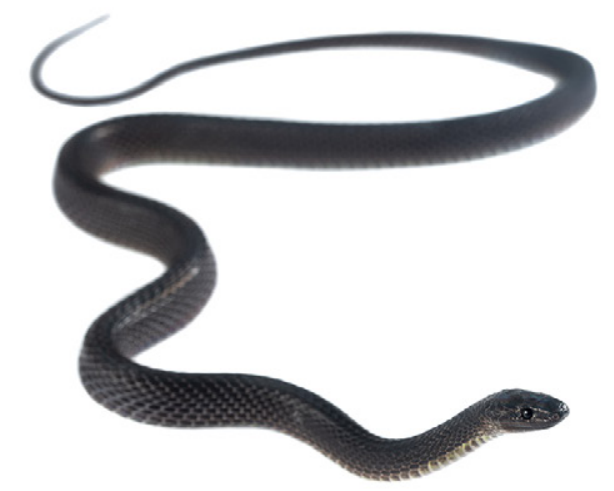

B
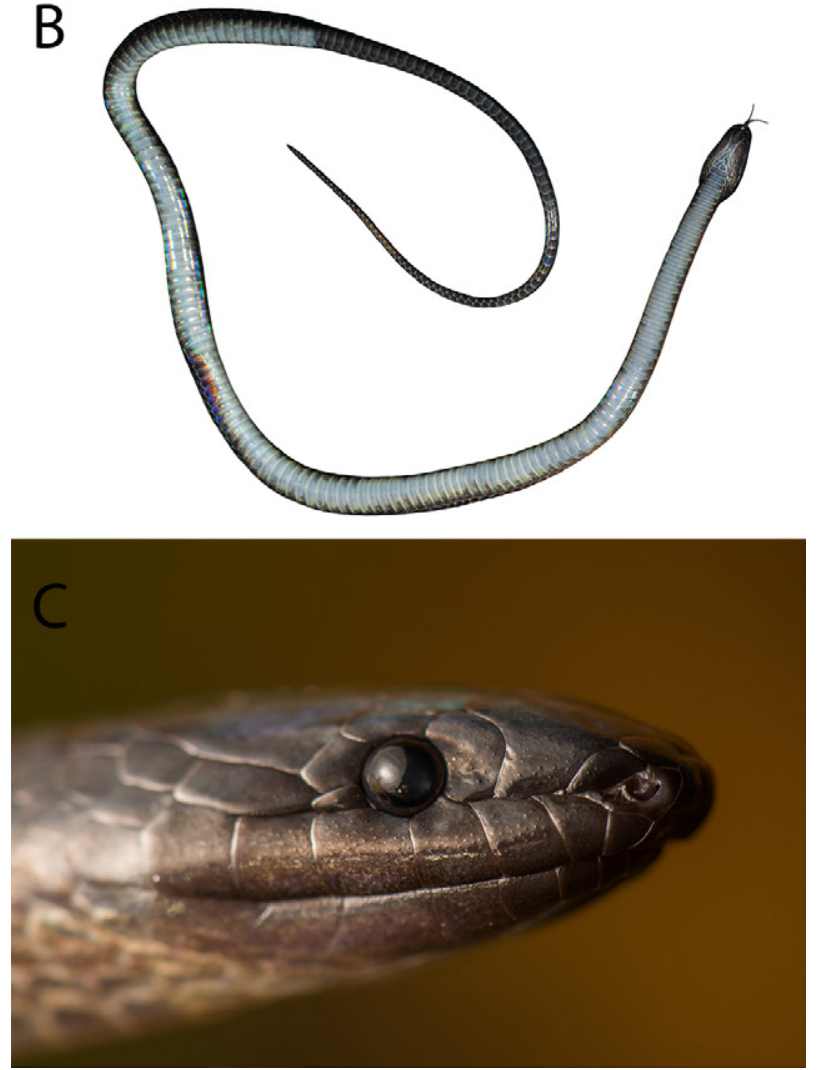

Figure 2. Emmochliophis fugleri in life. A. Dorsal view, LBE-USFQF-2020-001. B. Ventral view, LBE-USFQ-F-2020-002. C. Lateral view of head, LBE-USFQ-F-2020-003. Images: RJM (A,B); SJT (C).

stream; $19.8{ }^{\circ} \mathrm{C}, 96 \%$ relative humidity, and light rain; photo vouchers LBE-USFQ-F-2020-001-03; 1 adult, uncollected.

Based on this record and the holotype, E. fugleri appears to be restricted to the foothills and lower occidental slopes of the Andes in northwestern Ecuador. The type specimen was reported from $4 \mathrm{~km}$ east of the Río Baba bridge, $24 \mathrm{~km}$ south of Santo Domingo de los Colorados, Santo Domingo de los Tsáchilas, ca. 600 m (Fritts and Smith 1969). Our record from western Imbabura Province extends its known distribution ca. $93 \mathrm{~km}$ in a straight-line to the north-northeast (Fig. 1) and expands the elevational range from 600 to $1221 \mathrm{~m}$. Examination of photos from online databases of similar species (i.e., Diaphorolepis wagneri, Ninia atrata, N. teresitae, Synophis bicolor, S. calamitus) did not yield previously
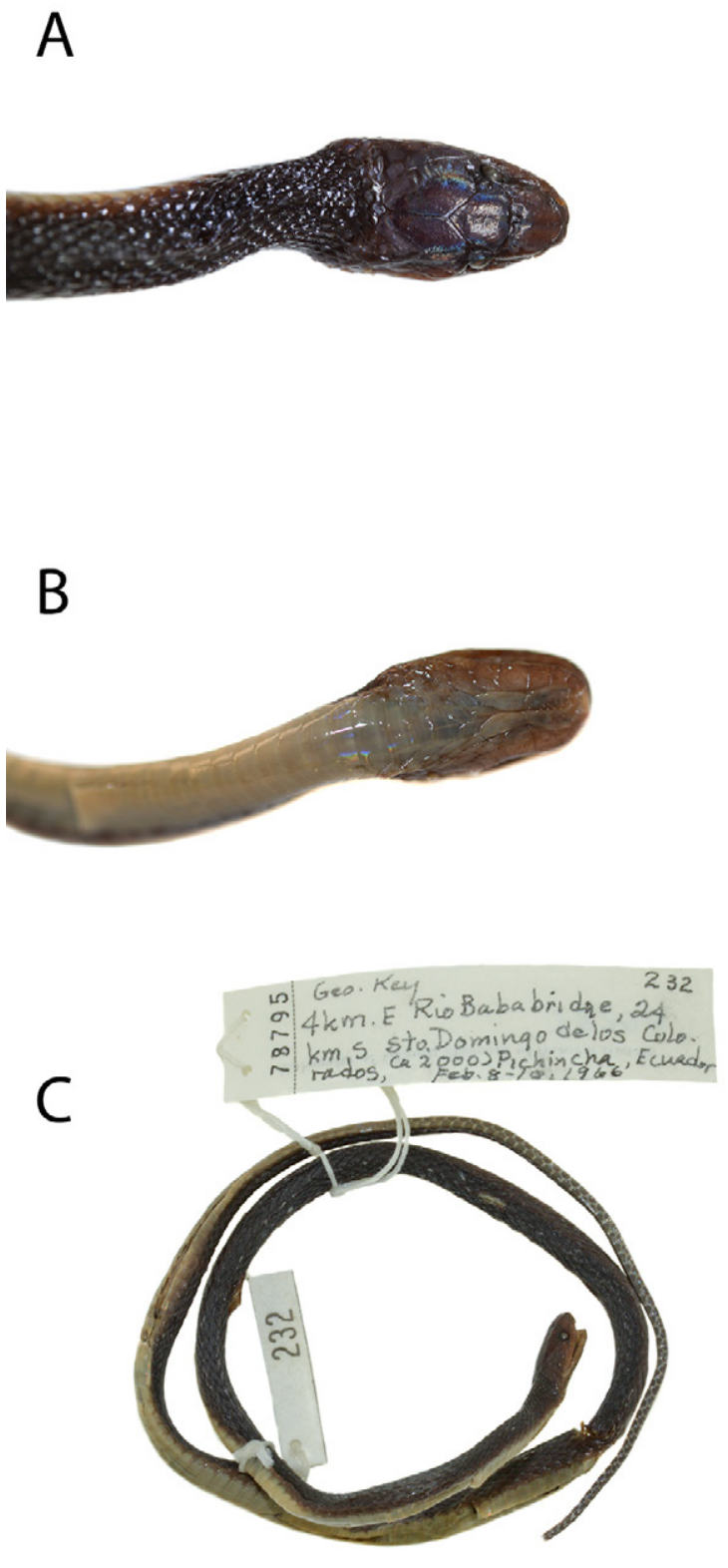

Figure 3. Emmochliophis fugleri holotype UIMNH 78795 A. Dorsal view of head. B. Ventral view of head. C. Full body. Images provided by Daniel B. Wylie.

overlooked observations of E. fugleri.

Identification. Characters exhibited by the individual observed at RMR that confirm its identity as Emmochliophis fugleri include: (1) vertebral scale row not expanded, single keel; (2) dorsal scales keeled, in 19-19-19 rows; (3) fused prefrontals; (4) loreal absent; (5) one preocular; (6) two postoculars; (7) temporals $1+2$; (8) eight supralabials, 4th and 5th in contact with orbit; (9) eight infralabials ; (10) 134 ventrals; (11) 88 subcaudals, divided (complete tail); (12) anal plate entire; (13) dorsum uniformly black/ dark grey (in life), nuchal collar absent; (14) venter offwhite from the second pair of chin shields to the anal plate, dark brown/copper where the dorsal/ventral colorations transition along the lower flanks/lateral peripheries of the venter; ventral surface of head dark grey/diffuse brown, ventral surface of tail dark grey (Fig. 2; Table 1). 
The following characters exhibited by LBE-USFQF-2020-001-03 distinguish it from other members of Diaphorolepidini, as well as other similar species: prefrontals fused (divided in Ninia spp.), an unexpanded intervertebral scale row with a single keel (expanded with a double keel in Diaphorolepis spp.); loreal scale absent (present in Diaphorolepis spp., Ninia spp., and

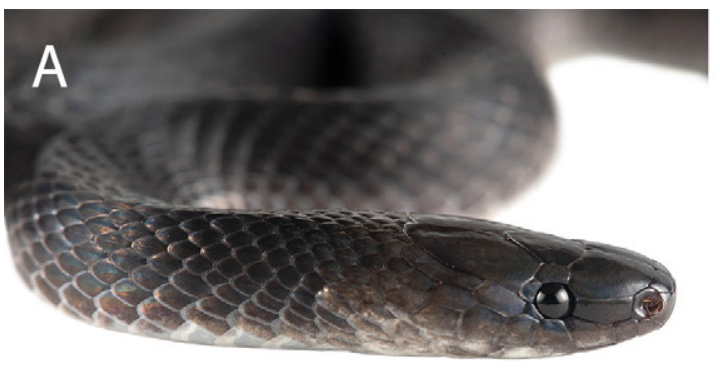

C

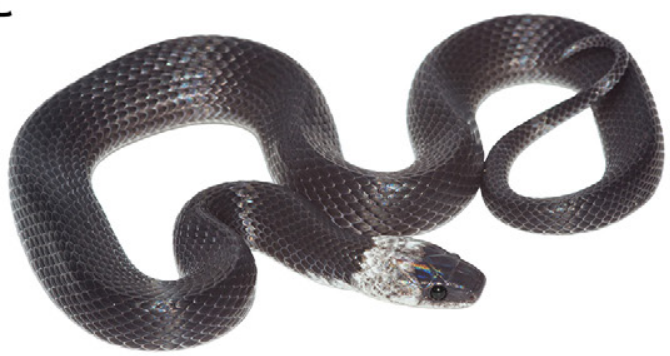

D
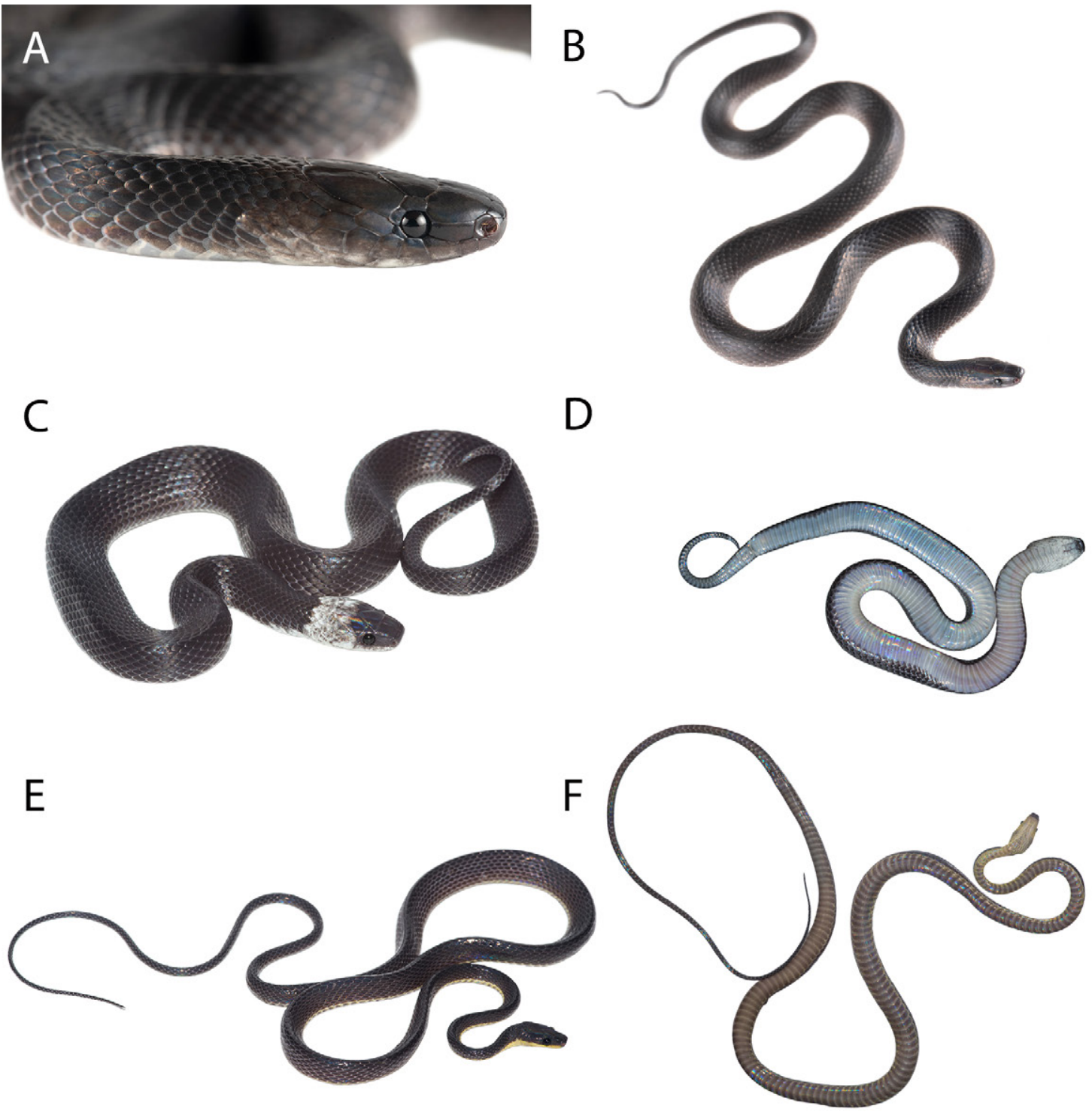

G
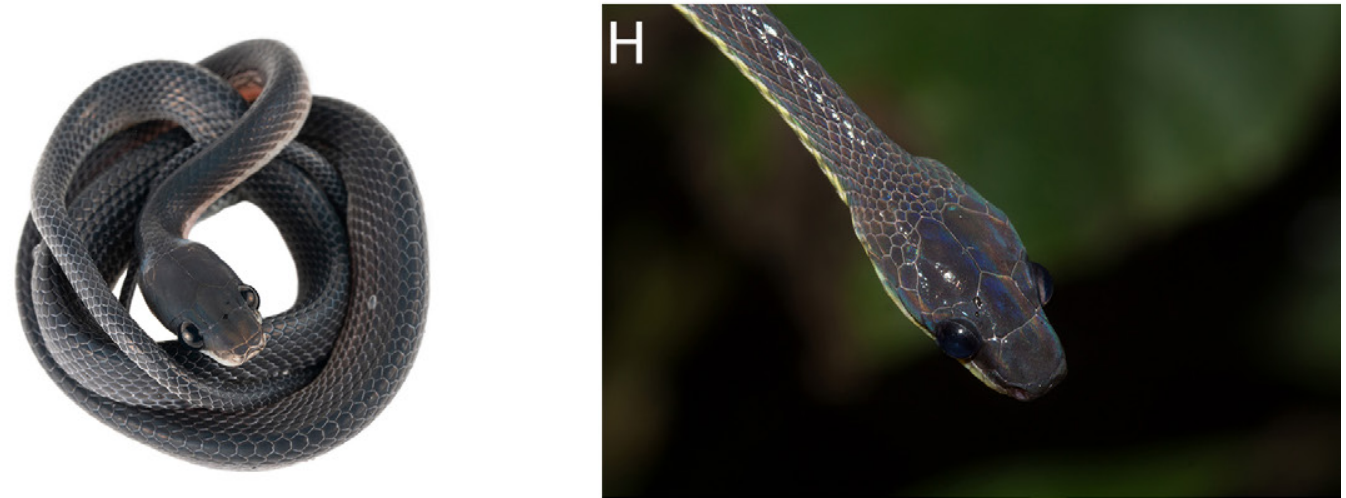

Figure 4. Similar species to Emmochliophis fugleri known from the Río Manduriacu Reserve and nearby sites. A, B. Ninia teresitae without white nuchal band (from Estación Biológica Jevon, Esmeraldas, Ecuador). C, D. Dorsal and ventral view of Ninia atrata from RMR with nuchal band E, F. Dorsal and ventral view of an adult Diaphorolepis wagneri from RMR. G, H. Examples demonstrating variation in the condition of the prefrontal in D. wagneri: (G) divided; $(\mathbf{H})$ fused. Images: JC (A, B, G); RJM (C-F, H). 
holotypes at the time they were last assessed for the IUCN Red List, E. fugleri was assessed as Data Deficient (Cisneros-Heredia and Yánez-Muñoz 2016) and E. miops as Critically Endangered (Cisneros-Heredia and YánezMuñoz 2017). We recommend the status of E. fugleri to be reclassified from Data Deficient to Critically Endangered based on criterion B2ab(ii,iii,iv), as this species has one location where the threat is mining (Roy et al. 2018; Guayasamin et al. 2019). Moreover, no additional specimens have been reported from within the area between the type locality and RMR, which is largely characterized by severe forest fragmentation due to timber extraction, agriculture, and cleared pastures, which continue to expand in the immediate area south of the reserve (Maynard et al. 2020).

Remarks. The snout-vent length (SVL) and tail length (TL) of the holotype (UIMNH 78795) have not previously been reported and are as follows: $\mathrm{SVL}=259.0$ $\mathrm{mm} ; \mathrm{TL}=132.5 \mathrm{~mm}$ (tail slightly incomplete; Fig. 3). The SVL and TL of the specimen from RMR were not measured; however, we estimate the total length (SVL + TL) to be ca. $345.0 \mathrm{~mm}$. Based on the size of the three measured specimens of E. miops (Vera-Pérez et al. 2020) as well as the holotype of E. fugleri, we suspect the individual of E. fugleri from RMR was a young adult. Our estimate of its TL is based on the snake's relative size to the glass plate on which it was placed for images of the venter. If we then take the average of the TL/SVL ratios for the two specimens of E. miops that have complete tails and the holotype of E. fugleri (only tip of tail missing), a rough estimate of the SVL and TL of voucher LBE-USFQ-F-2020-001 yields $229 \mathrm{~mm}$ and $116 \mathrm{~mm}$, respectively (Table 1).

Diagnostic apomorphies in Diaphorolepidini. Although the presence of fused prefrontals is reported as diagnostic for all members of the tribe (Pyron et al. 2016), observations of Diaphorolepis wagneri from RMR have exhibited both divided and fused prefrontals (Fig. 4). Therefore, a fused prefrontal is not a definitive diagnostic character for Diaphorolepis, or rather should not be considered as an identifying meristic character used to distinguish Diaphorolepis when the prefrontals are divided.

\section{Discussion}

The discovery of Emmochliophis fugleri at the Río Manduriacu Reserve represents the first record of the species since the holotype was collected in 1966 (i.e., 54 years). Considering that our observation of E. fugleri and the recent rediscovery of E. miops by Vera-Pérez et al. (2020) were both tentatively field-identified as one of the more common Ninia species due to their similarities in appearance (i.e., small size, black dorsum, light venter, dark eyes, and a white nuchal band that may be present or absent), the absence of misidentified observations from our search of online databases is somewhat surprising and further suggests that these species are indeed rare.
Moreover, although the site of observation of E. fugleri in RMR is the most thoroughly surveyed area of the reserve, no other observations have been made.

It appears that both members of Emmochliophis require humid, interior forest conditions (CisnerosHeredia and Yánez-Muñoz 2016; Cisneros-Heredia and Yánez-Muñoz 2017; Vera-Pérez et al. 2020). When the holotype of E. fugleri was collected 54 years ago, the general area in which it was found was described as being "covered largely with banana plantations broken only occasionally by patches of rain forest" (Fritts and Smith 1969: 64). Considering the substantial amount of deforestation that has occurred in this region of western Ecuador, which largely began less than a decade prior to the holotype being collected (Dodson and Gentry 1991), it seems unlikely that this species still persists at the type locality. Based on the coordinates provided in Pyron et al. (2015), these small forest fragments lie immediately east of where the holotype was collected and represent a small chain of hills extending west from the base of the Andes that form a narrow backbone of higher elevation from the surrounding area (i.e., 700-950 m). However, it is unclear if deforestation had isolated these forested hills at the time the holotype was collected. Based on the two known localities of E. fugleri, it is also unclear whether or not the species is primarily an inhabitant of the humid forests of the Chocoan lowlands or the lower Andean forest of the Occidental slopes in northwestern Ecuador.

Future studies should assess the phylogenetic position of the genus, and to confirm that E. fugleri and E. miops are indeed distinct lineages. Nevertheless, the presence of E. fugleri at RMR further demonstrates the conservation importance of the reserve (Lynch et al. 2014; Guayasamin et al. 2019; IUCN SSC Specialist Group 2019, 2020; Maynard et al. 2020; Reyes-Puig et al. 2020).

\section{Acknowledgements}

We thank Daniel B. Wylie for providing measurements and images of the holotype of E. fugleri (UIMNH 78795). We also thank the Ministerio de Ambiente y Agua del Ecuador for providing research permits. Access to the reserve was facilitated by Fundación EcoMinga. We are grateful to Lou Jost, Cord Eversole, and John Murphy for providing helpful input on the manuscript. Lastly, the authors are indebted to the community of Santa Rosa de Manduriacu for logistical assistance, hospitality, and support of this study.

\section{Authors' Contributions}

RJM wrote the manuscript; RJM, JC, SK, and SJT conducted field work; RJM and JC performed the literature review; JC created the distribution map; RJM created the remaining figures, with photo contributions from RJM, SJT, and JC; JMG accessioned photo vouchers; SJT, $\mathrm{JC}$, SK, and JMG reviewed and provided input on the manuscript. 


\section{References}

Angarita-Sierra T, Lynch JD (2017) A new species of Ninia (Serpentes: Dipsadidae) from Chocó-Magdalena biogeographical province, western Colombia. Zootaxa 4244 (4): 478-492. https://doi.org/ 10.11646/zootaxa.4244.4.2

Bequpre SJ, Jacobson ER, Lillywhite HB, Zamudio K (2004) Guidelines for use of live amphibians and reptiles in field and laboratory research. American Society of Ichthyologist and Herpetologists, Lawrence, Kansas, USA, 43 pp.

Bogert CM (1964) Snakes of the genera Diaphorolepis and Synophis and the colubrid subfamily Xenoderminae (Reptilia, Colubridae). Senckenbergiana Biologica 45: 509-531.

Boulenger GA (1898) An account of the reptiles and batrachians collected by Mr. W.F.H. Rosenberg in Western Ecuador. Proceedings of the Zoological Society of London 1898: 107-126.

Cisneros-Heredia DF, Yánez-Muñoz M, Valencia J (2016) Emmochliophis fugleri. The IUCN Red List of Threatened Species 2016 e.T50951446A50951451. https://doi.org/10.2305/IUCN.UK.20161.RLTS.T50951446A50951451.en. Accessed on: 2020-9-16.

Cisneros-Heredia DF, Yánez-Muñoz M (2017) Emmochliophis miops. The IUCN Red List of Threatened Species 2017: e.T50951457A 50951496. https://doi.org/10.2305/IUCN.UK.2017-2.RLTS.T50951 457A50951496.en. Accessed on: 2020-9-16.

Dodson CH, Gentry AH (1991) Biological extinction in western Ecuador. Annals of the Missouri Botanical Garden 78 (2): 273-295.

Dowling HG (1951) A proposed standard system of counting ventrals in snakes. British Journal of Herpetology 1: 97-99.

Fritts TH, Smith HN (1969) A new genus and species of snake from western Ecuador. Transactions of the Kansas Academy of Science 72: 60-66. https://doi.org/10.2307/3627049

Guayasamin JM, Cisneros-Heredia DF, Vieira J, Kohn S, Gavilanes G, Lynch RL, Hamilton PS, Maynard RJ (2019) A new glassfrog (Centrolenidae) from the Chocó-Andean Río Manduriacu Reserve, Ecuador, endangered by mining. PeerJ 7: e6400. https://doi.org/ 10.7717/peerj.6400

Hillis D (1990) A new species of xenodontine colubrid snake of the genus Synophis from Ecuador and the phylogeny of the genera Synophis and Emmochliophis. Occasional Papers of the Museum of Natural History University of Kansas 135: 1-9.

IUCN SSC Amphibian Specialist Group (2019) Rhaebo olallai. The IUCN Red List of Threatened Species 2019: e.T54463A49340530. https://doi.org/10.2305/IUCN.UK.2019-1.RLTS.T54463A49340 530.en. Accessed on: 2020-9-10

IUCN SSC Amphibian Specialist Group (2020) Nymphargus manduriacu. The IUCN Red List of Threatened Species 2020: e.T149692574A149692615. https://doi.org/10.2305/IUCN.UK.20
20-3.RLTS.T149692574A149692615.en. Accessed on: 2021-1-12

Lynch RL, Kohn S, Ayala-Varela F, Hamilton PS, Ron S (2014) Rediscovery of Andinophryne olallai Hoogmoed, 1985 (Anura, Bufonidae), an enigmatic and endangered Andean toad. Amphibian \& Reptile Conservation 8 (1): 1-7.

Maynard RM, Trageser SJ, Kohn S, Hamilton PS, Culebras J, Guayasamin JM (2020) Discovery of a reproducing population of the Mindo Cochran Frog, Nymphargus balionotus (Duellman 1981), at the Río Manduriacu Reserve, Ecuador, with a literature review and comments on its natural history, distribution, and conservation status. Amphibian \& Reptile Conservation 14 (2): 172-184.

Pérez-Santos C, Moreno AG (1988) Ofidios de Colombia. Museo Regionale di Scienze Naturali, Torino, Italy, $517 \mathrm{pp}$.

Pérez-Santos C, Moreno AG (1991) Serpientes de Ecuador. Museo Regionale di Scienze Naturali, Torino, Italy, $538 \mathrm{pp}$.

Pyron, RA, Guayasamin JM, Peñafiel N, Bustamante L, Arteaga A (2015) Systematics of Nothopsini (Serpentes, Dipsadidae), with a new species of Synophis from the Pacific Andean slopes of southwestern Ecuador. ZooKeys 541: 109-147. https://doi.org/10.3897/ zookeys.541.6058

Pyron RA, Arteaga A, Echevarría LY, Torres-Carvajal O (2016) A revision and key for the tribe Diaphorolepidini (Serpentes: Dipsadidae) and checklist for the genus Synophis. Zootaxa 4171: 293-320. https://doi.org/10.11646/zootaxa.4171.2.4

Reyes-Puig C, Maynard RJ, Trageser SJ, Vieira J, Hamilton PS, Lynch R, Culebras J, Kohn S, Brito J, Guayasamin JM (2020) A new species of Noblella (Amphibia: Strabomantidae) from the Río Manduriacu Reserve on the Pacific slopes of the Ecuadorian Andes. Neotropical Biodiversity 6 (1): 162-171. https://doi.org/10.1080/2 3766808.2020.1809287

Roy BA, Zorrilla M, Endara L, Thomas DC, Vandergrift R, Rubenstein JM, Policha T, Rios-Touma B, Read M (2018) New mining concessions could severely decrease biodiversity and ecosystem services in Ecuador. Tropical Conservation Science 11: 1-20. https://doi.org/10.1177/1940082918780427

Sheil CA (1998) Emmochliophis miops: redescription of Synophis miops (Boulenger, 1898). Journal of Herpetology 32: 604-607. https://doi.org/10.2307/1565222

Vera-Pérez LE, Zúñiga-Baos JA, González SA (2018) Reptiles del Parque Nacional Natural Munchique, Colombia. Revista Novedades Colombianas 5: 97-131.

Vera-Pérez LE, Campbell PD, Montingelli GG (2020) Rediscovery and redescription of the rare, Critically Endangered snake Emmochliophis miops (Serpentes: Colubridae), with comments on its natural history, distribution, and phylogenetic relationships. Phyllomedusa 19 (1): 3-12. https://doi.org/10.11606/issn.2316-9079. v19ilp3-12 